\title{
CONCOMITANT TYPHOID INFECTION IN URINARY SCHISTOSOMIASIS IN SOUTH EASTERN NIGERIA.
}

V. O. NWAUGO, F. O. MDUKA and M. C. MWACHUKWU

(Received 16 July, 2004 ; Revision accepled 3 January, 2005)

\section{ABSTRACT}

Concomitant typhoid fever infections in Urinary Schislosomiasis was investigated using bolt stool cullure and serological techniques (widal test). Of the 503 urinary s: istosomiasis patients screened $233(46.32 \%)$ were typhoid fever positue by culture method while $259(51.49 \%)$ were positive with widal test. Controls only gave $10 \%$ positive results. Statistical analysis showed no significant difference in the diagnostic methods but significant typhoid prevalence among the schistosomiasis patients $\left(X^{2}=P=\right.$ 0.05). There was no significant difference in the concomitant infection belween the males and femal's but individuals betveen 1020 and $20-30$ years of age years of age were significantly mo e infected than those of other age groups.

\section{INTRODUCTION}

Schistosomiasis, caused by species of trematode Schistosoma, is a parastic disease of great soico-economic and public health importance, second only to malaria. (Roger, 1986, WHO, 1992, 1994). Several species are known but few have been implicated in human infections which include $S$ h ematobium, $S$ japonicum, $S$ mansoni, $S$. mansoni, $S$. mekongi, $\mathrm{S}$ mattheei and $\mathrm{S}$. intercalatum (Arene et al, 1989, WHO, 1994). Several millions of people are infected in 74 to 82 countries with over 20 million being clinically morbid or disabled (Garfield, 1991, WHO, 1994). The disease is mainly chronic (Frandsen, 1979; Savioli and Mott, 1989).

Parasitic disease, though caused by larious parasites (heiminth, protozoa, nematodes, etc) are aggravated by concomitant microbial infections. Nduka et al. (1993) had reported the aggravation of paragonimiasis by concomitant or secondary bacterial infections especially during hemoptysis in parts of South Eastern Nigeria, Chessbrough (1984) and ook (1990) reported the observation of Salmonella irfection in Schistosomiasis of S. mansoni origin

This work therefore sets out to investigate the prevalence of typhoid infection in the urinary schistosomiasis endemic area with regards to age and sex of the people. In addition, the use of serological test (Widal test) as a diagnostic procedure in sich an area will also be examined.

\section{MATERIALS AND METHODS}

The study area was Umuchieze which lies at the Northern part of Abia State, Nigeria. All specimens were analyzed in Abia State University, Uturu Department of Microbiology Laboratory.

\section{SANIPLE COLLECTION}

Two clinical specimens were collected during this work. Stool specimens were obtained in sterile wide mouthed plastic containers with cover from 503 urinary Schistosomasis patients identified during the preliminary survey. The preliminary survey involved the microscopic examinatic:, of subjects urine for the characteristically terminally spined eggs of S. haematobium. The urine specimens with the eggs wee taken as positive, those without eggs were negative and taken as controls. Stool and blood collected by venepuncture, were also collected from 200 Schistosomiasis negative individuals as controls.

\section{EXAMINATION OF SPECIMENS}

The stool specimens were inoculated on prepared Deoxycholate Agar (DCA) and Salmonella Shigella Agar (SSA) plates and incubated at $37^{\circ}$ for $24-48$ hours in Gallenkamp ordinary incubator. Observed bacterial colonies (colonies which turned black after 24 hours on DCA) were sub-cultured for pure isolates and subjected to microscopy (after staining) and some biochemical test for characterization and identification. The biochemical tests carried out include indole, Methyl Red Voges-Proskatuer and Citrate Utilization tests. Others include Urease, Oxidase, Nitrate reduction, Hydrogen Sulphide production and sugar fernentation tests. The sugar tested were Glucose, Mannitoll Maltose, Xylose and Arabinose

The blood specimens were allowed to stand at room temperature for 1 hour in order to ciot. The serum obtained was subjected to Widal test malysis using Biomed kits. Typhoid positive serum was taken as that with visibie agglutination at $21: 160$ dilution.

\section{RESULTS}

Five hundred and three urinary Schistosomiasis - positive patients and two hundred Schistosomiasis - negative individuals were screened for typhoid fever using both culture and serological test (Widal). Of the 503, 233 (46.32\%) of the urinary Schistosomiasis patients were observed to be typhoid fever positive using culture method, while 259 (51.49\% were observed positive based on Widal test technique. The control gave only $10 \%$ positive in each method used (Table 1 ). Statistical analysis showed a significant typhoid fever prevalence among the Schistosomiasis patients $\left(X^{2}=P\right.$. 05). The diagnostic technique used did not give any statistically different result $\left(X^{2}=\right.$ P.05).

Of the 317 males and 186 females screened, 151 (47.63\%) males and $82(44.09 \%)$ females were infected using culture method. The Widal test results showed $167(52.68 \%)$ of the 317 males and $92(49.66 \%)$ of the females as positive for typhoid. There was no significant difference in the prevalence of typhoid fever between the males and females in the area.

Subjects between $10-20$ and $21-30$ years age groups were significantly more infected than those of other age groups $(\times 2$ $=$ P.05) (Table 2). Similar trends were observed using both types of diagnostic (Serological and culture) procedures.

V. O. NWAUGO, Department of Microbiology, Abia State University, Uturu, Nigeira.

F. O. NDUKA, Department of Animal and Environmental Biology, Abia State University, Uturu, Nigeria.

N. C. NWACHUKWU, Department of Microbiology, Abia State Universitv, Uturu, Nigeira. 
TABLE 1: PREVALENCE OF TYPHOID INFECTION AMONG URINARY SCHISTOSOMIASIS PATIENTS IN THE STUDY AREA:

\begin{tabular}{|l|c|c|c|c|c|c|c|c|}
\hline & \multicolumn{4}{|c|}{ TEST SPECIMENS } & \multicolumn{3}{c|}{ CONTROLS SPECIMENS } \\
\hline $\begin{array}{l}\text { Methods } \\
\text { Diagnosis }\end{array}$ & NE & NI (\%) & NE & Ni (\%) & Total & NI(\%) & NE & N1(\%) \\
\hline culture (stool) & 317 & $151(47.63)$ & 186 & $82(44.09)$ & 503 & $233(46.32)$ & 200 & $20(10)$ \\
\hline $\begin{array}{l}\text { Widal Test } \\
\text { (Blood Serum) }\end{array}$ & 317 & $167(52.68)$ & 186 & $92(49.46)$ & 503 & $259(51.49)$ & 200 & $20(10)$ \\
\hline
\end{tabular}

$\begin{array}{lll}\text { KEY: } & \\ \text { NE } & = & \text { Number Examined } \\ \text { N1 } & = & \text { Number Infected } \\ \% & = & \text { Percentage of each group infected in bracket. }\end{array}$

TABLE 2: PREVALENCE OF TYPHOID INFECTION AMONG URINARY SCHISTOSOMIASIS PATIENTS OF DIFFERENT AGE GROUPS IN QUARRY PITS SITE OF. DIAGNOSTIC TECHNIQUES

\begin{tabular}{|c|c|c|c|c|c|c|}
\hline & \multicolumn{3}{|c|}{$\begin{array}{c}\text { CULTURE TECHNIQUE } \\
\text { (STOOL) }\end{array}$} & \multicolumn{3}{c|}{ WIDAL TEST (BLOOD } \\
\hline YEARS & NE & NI & $\%$ & NE & NI & $\%$ \\
\hline $0-10$ & 50 & 24 & 42.1 & 50 & 24 & 48 \\
\hline $11-20$ & 210 & 98 & 46.67 & 210 & 112 & 53.33 \\
\hline $21-30$ & 164 & 76 & 40.34 & 164 & 84 & 51.22 \\
\hline $31-40$ & 56 & 26 & 46.43 & 56 & 27 & 48.22 \\
\hline $41-50$ & 15 & 6 & 40 & 15 & 8 & 53.33 \\
\hline 51 and & 8 & 3 & 37.51 & 8 & 4 & 50.00 \\
above & & & & & & \\
\hline TOTAL & 503 & 233 & 46.32 & 503 & 259 & 51.49 \\
\hline
\end{tabular}

KEYS:

$\begin{array}{lll}\text { NE } & = & \text { Number of individuals examined in each group } \\ \mathrm{NI} & = & \text { Number of individuals infected in each group } \\ \% & = & \text { Percentage of individuals infected. }\end{array}$

\section{CQNFIRMATION OF THE ISOLATES AS SALMONELLA SPECIES}

The isolates were motile, gram negative rods which were indole negative, Mr positive, VP negative and Citrate negative. The other characteristics are shown in table 3.

\section{CONFIRMATION OF THE SUBJECTS AS TYPIDID PATIENTS}

A second set of specimens (stool and blood) were obtained from the urinary schistosomiasis positive and negative subjects and subjected to both culture and serological tests again for confirmation of the typhoid cases. The second set of specimens were collected four to five days after the first one. Those "that remained positive in both sets of tests were regarded in this work as positive cases.

\section{DISCUSSION}

In this investigation, the culture of stool specimens from 503 urinary Schistosomiasis patients yielded $40.32 \%$ positive Salmonella species isclates. Screening using serological test (Widal) gave $51.43 \%$ positive typhoid infection. The results obtained from both diagnostic techniques suggest high typhoid prevalence among the urinary Schistosomiasis patients. This is more remarkable as only $10 \%$ of the 200 urinary Schitosomiasis negative individuals gave positive result.
Though the values observed in this work are high, thsy are still lower than $72 \%$ observed in Singapore by Pong and Puhuchery (1993) but higher than the $32 \%$ sec in

Cawden and Noah (1989). Singapore and Egypt at wote: mainly inlestinal Schistosomiasis. Endemicity.

The high prevalence of typhoid fever observed in this work is due to several factors. According to Cook (1990) and Chessbrough (1984), typhoid is common intestinal Schistosomiasis endemic area and Schistosomiasis has been show to be endemic in Umuchieze, the study area (Nduka ot al., 1995, Nwaugo 1998). Frequent outbreaks and endemicity of typhoid fever is a common feature of areas with low sanitary standard and poor hygiene (Rao ef al., 1980. Stephen et al., 1984). Nduka of al., (1993, 1995) and Nwaugo (1998) had reported this low hygiene level in the area.

It was observed that widal test gave slightly higher, though statistically insignificant values than culture method. The difference, though not significant shows some important features. Chew et al (1992) had observed similar occurrence in their study in Singapore. Cook (1990) and Chessbrough, (1984) have suggested that the higher values observed in Widal test method could be due to the production of the anti bodies by Schistosoma species which could cross react with the antigens produced by the Saimonella species. Chew et al 
TABLE 3: CHARACTERISTICS OF THE SALMONELLA SPECIES

ISOLATED FROM THE STOOL

SPECIMEN EXAMINED.

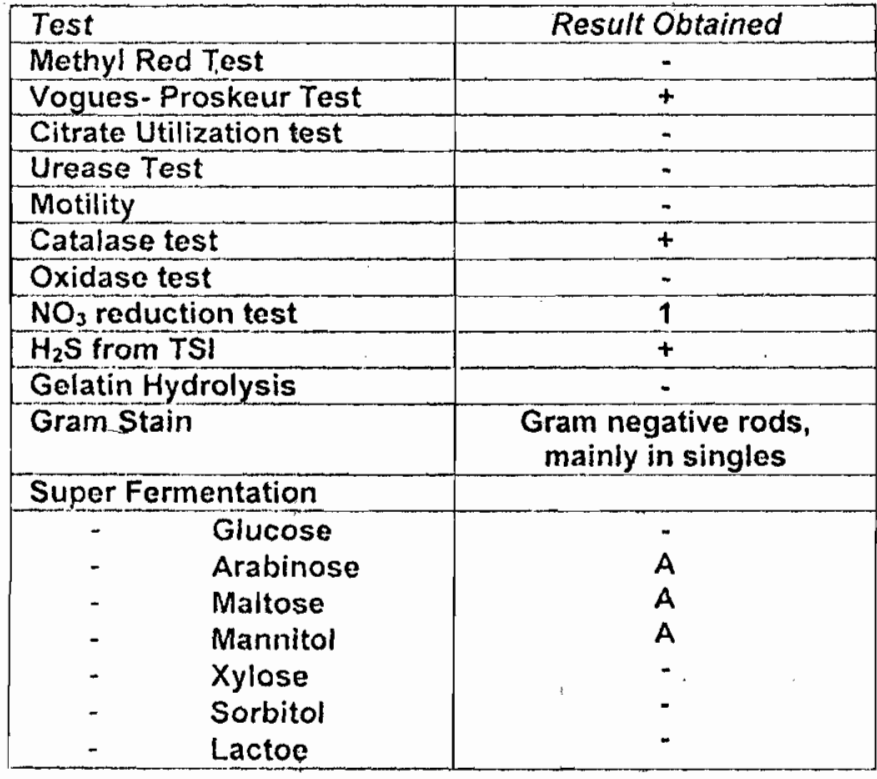

Key:

$+\quad=$ Positive

- $\quad=$ Negative

A $=$ Acid

NB: $\quad$ All tests were carried out as described by Chessbrough (1987).

(1992) Hernandez - Velardi et al (1980) and Levine et al) agree that there could be small differences between cultural and Serological evidences in typhoid. Pong and Puthucheny (1n89) and Rao et al (1990) have aiso observed similar situations with, the minor differences belween culture and serological diagnostic methods.

Results obtained in this work showed that the sex of the individual did not play any role in the concomitant infection of Schistosomiasis and typhoid infections. This implies that the only important factor was the presence of the Schistosomiasis disease, which predisposed the subjects to typhoid infection. However, this was not the same with age as subjects between t0-20 and 21-30 years age groups were significantly more infected $(P=0.05)$ than those of other age groups. Nduka et al (1993,.1995) had reported that subjects of $10-20$ years generally are more adventurous than other age gruups. In a similar vein. Ferrecio et al (1989) and Levine et al (1978) had stated that typhoid fever was more prevalent in adolescents and young aduits than in older subjects.

In conclusion, this work agrees that high typhoid prevalence is common in Schistosomiasis endemic areas but not limited to intestinal Schistosomiasis, meaning that both urinary and intestinal Schistosomiasis can predispose one to typhoid fever infection. In addition, the study confirms that Widal test and cultures techniques are still reliable diagnostic tools in typhoid diagnosis.

\section{REFERENCES}

Arene, F. O. Ukpeibo, E.T. and Nwanze E. A., 1989. Studies on Schistosomiasis in the Niger Delta, S. Interalatum in the Urban City of Port Harcount, Nigeria Public Health 103 (4): 295-301.
Chessbrough, M., 1984. Medical Laboratory Manual for Tropic Countries. $3^{\text {rd }}$ Edition (ELBS) Tropical Health Technology and Butterworth London.

Chew, S. K. Cnizi, M. S. P., Irim, Y. S. and Monteiro, E. H., 1992. Diagnostic value of the Widal test for typhoid fever in Singapore. Journal Tropical Medicine and Hygiene. 95: $288: 291$

Cook, G. C., 1990. Parasitic disease in Clinical Practice. The Bloomsburg. Series in Clinical Services. SpringerVer-Log London, Paris 340-365.

Cowden, J. M. and Naoh, N. D., 1989. Salmonella and eggs. Archeology of Disease in Childhood. 64: 1419-1420.

Ferreccio, C. Levine, M. M. and Materola, A., 1984. Benign bacteriemia caused by Salmonella typhi and $S$. paratyphi in children younger than 2 years. Journal of Pediatrics. 104: 899-901.

Frandson F. C., 1979. Studies of the relationship between Schistosoma and their intermediate hosts II. The Genus Bulinus and S. Heamatobium from Sudan Zaire and Zambia. Journal of Helminthology 49: 73 . 84.

Garfield, 1996. Schistosomiasis. The Scourge of the third world, part II. Diagnosis and treatment. Cyrrent Comments 10:3-8.

Hernandez-velardl, R., Sanchez-Castillo, J., Diaz-Condmez, M. Munoz-Hernandez, O., 1980. Detection of antibodles to Salmonella ' $O$ ' antigen in typhoid fever by counter immuno-electrophere. Arch. Investment in medicine 10:23-25 
Igbozurike. M., 1986. The Isuikwuato Okigwe Region. Rato press, Owerri Nigeria,

Levine, M.M. Grados D., Gilman, R.H., Woodward, W.E. Solisplaza, R, and Waldman, W., 1978. Diagnostic value of widal test in areas endemic for typhoid fever American Joumal of Tropical Medicine and Hygiene 27: 795-800.

Noluka, F. O.. Nwaugo, V. O and Nwachukwu, N. C.. $1993 a$. Bacterial associated with paragonmiasis infection in Okigwe area of Imo State. Nigeria. Nigerian Journal of Biotechnology 11: 66-75

Noluka, F. O Ajaero, C.M.U. Nwoke, B.EB., 1995. Urinary Schislosomiasis among school children in an endemic communily in South eastern Nigeria. Applied parasitilogy, 36: $34-40$

Nwauge, V. O., 1998. Aspects of the epidemiology of Urinary Schistosomiasis and Blonomics of Bulinus species (Intermediate host of $\mathbf{S}$ haematobium) in Quarry pits of Umuchieze Abia State Nigeria. Ph.D Thesis Abla Stato University, Uturu Nigeria.

Pang .T and Puthucheary, S.D. (1989): False positive widal test in non-typhoid Salmonella infection. South East Asian Journal of Tropical Medicine and Public Health. 20:163-165.
Roa, R.S. Sundawaraj J. Paramasiva, C.N. 7 Sabrammuman, N. 1990. Widal test as a diagnostic aid-an appraisal. Indian journal of Microbiology 20: 11-13.

Roger, $F_{.1}$ 1986. Advances in Parasitology Proceeding of International Congress of parasitilo gy (Howell, J. ed.). Australian Academy of Science 1:3.

Savioli I. and Mott, K.F., 1989. Urinary Schistosomiasis on Pemba Island, Low-cost diagnosis for control in Primary Health Care setting Parasitilogy Today $5(10)$ : 333-337.

Stephen, A.K James, J.J., Fredesick, S.B. and Phillip C.C. 1984. Typhoid fever, An epidemic with remarkably few clinical signs and symploms. Annals of Internal Medicine; 144: 533.537 .

WHO, 1992. Schistsomiasis progress 1991-1992. 11"1

. Programme Report UNDP World Bank WHO Special Programme for Research and training in Tropical Disease 2936.

WHO, 1992. Schistsomiasis, 20 years of progress, Highlights, 1993-1994. TDR $12^{\text {th }}$ Programme Report UNDP World Bank WHO Special Report for research (TDR) 77-86. 